\title{
CULTURAL EVENTS AS PART OF CULTURAL TOURISM DEVELOPMENT. CASE STUDY: SOMBOR AND APATIN (SERBIA)
}

Ivana Blešić, Tatjana Pivac, Jasmina Đorđević, Igor Stamenković, Sava Janićević

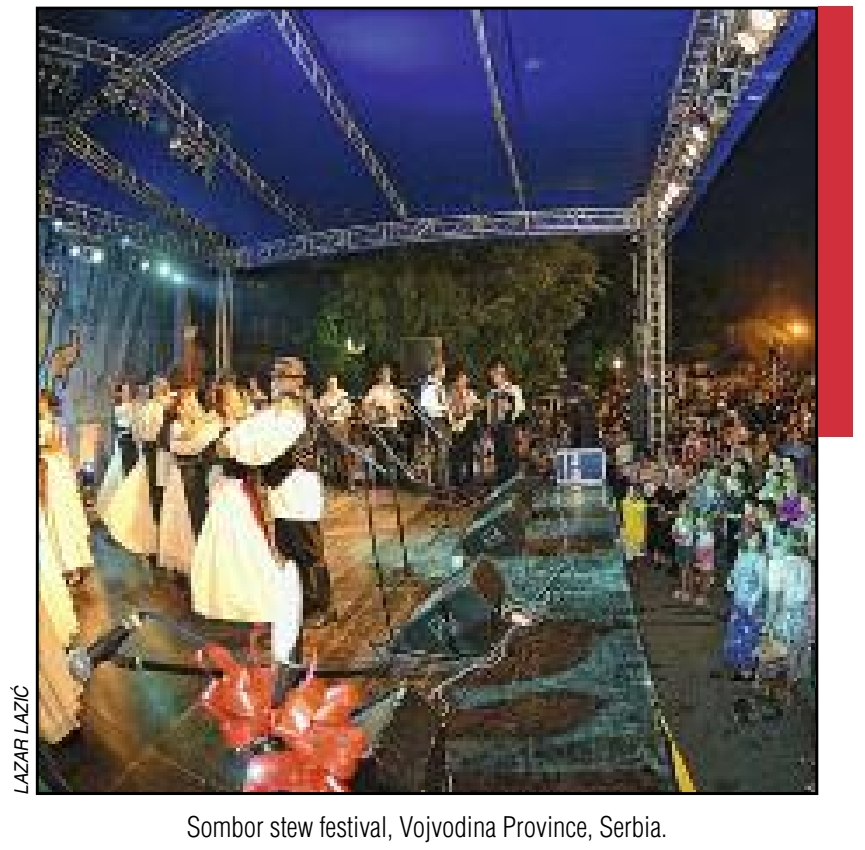




\title{
Cultural events as part of cultural tourism development. Case study: Sombor and Apatin (Serbia)
}

\author{
DOI: http://dx.doi.org/10.3986/AGS54406 \\ UDC: $913: 338.48(497.113)$ \\ 338.48-6:7/8(497.113) \\ COBISS: 1.01
}

\begin{abstract}
Festivals and special events play a significant role in communities' lives because they provide important activities and spending outlets for both locals and visitors, and enhance the tourist image of local communities and their social cohesion. Backgrounds and contents of events are various, but the most attractive ones are those devoted to gastronomy or those that cherish tradition, customs, folklore and handicrafts. The municipalities of Sombor and Apatin are multiethnic regions with authentic folklore and food out of which numerous events of economic and entertainment content emerged. The authors of this study recognized the most significant ten. The research is aimed at determining the attitudes of the local population with regard to the organization, realization and economic importance of cultural events.
\end{abstract}

KEY WORDS: festival, local population, attitudes, Sombor, Apatin, culture, tourism, regional development

The article was submitted for publication on December 19, 2012.

\section{ADDRESSES:}

Ivana Blešić, Ph. D.

Department of Geography, Tourism and Hotel Management

Faculty of Sciences

University of Novi Sad

Trg Dositeja Obradovića 3, 21000 Novi Sad, Serbia

E-mail: ivana.blesic@gmail.com

Tatjana Pivac, Ph. D.

Department of Geography, Tourism and Hotel Management

Faculty of Sciences

University of Novi Sad

Trg Dositeja Obradovića 3, 21000 Novi Sad, Serbia

Dositeja Obradovića 3, 21000 Novi Sad, Serbia,

E-mail: tatjana_pivac@yahoo.com

Jasmina Đorđević, Ph. D.

Department of Geography, Tourism and Hotel Management

Faculty of Sciences

University of Novi Sad

Trg Dositeja Obradovića 3, 21000 Novi Sad, Serbia

E-mail: jasminadjordjevic@live.com

Igor Stamenković, Ms. Sc.

Department of Geography, Tourism and Hotel Management

Faculty of Sciences

University of Novi Sad

Trg Dositeja Obradovića 3, 21000 Novi Sad, Serbia

E-mail: igorrrogi@yahoo.com

\section{Sava Janićević, Ph. D.}

Department of Geography, Tourism and Hotel Management

Faculty of Sciences

University of Novi Sad

Trg Dositeja Obradovića 3, 21000 Novi Sad, Serbia 


\section{Introduction}

In current economic climate, festivals play an important role for cities and whole regions. Festivals are considered to contribute significantly to cultural and economic development and as such have major impact on the development of cultural tourism to the host communities. The festival organizers are now using the historical and cultural themes to develop annual events to attract visitors and create cultural image in host cities by holding festivals in the community settings. The desire for festivals and events is not specifically designed to address the needs of any particular group. The hosting of events is often developed because of tourism and economic opportunities additional to social and cultural benefits. Festivals are being used by the organizers to express the relationship between identity and place and play a very important role in raising civic consciousness. Festivals are an important expression of human activity and contribute significantly to the social and cultural life of their host communities (Raj and Vignali 2010).

Events have the potential to generate a vast amount of tourism when they cater to visitors from other destinations plus the potential for grants, or sponsorships (Getz 1997), either by direct or indirect intent. The events in turn are seen as an important tool for attracting visitors and building the tourist image within different communities.

The main subject of this paper is the examination of how a form of tourism - event tourism- can affect rural development. How much does one rural event affect host communities? Can a small-scale event which takes place in a rural environment play significant role to the socio-economic development of the region?

This paper reports on research related to festivals' contribution to the development of cultural tourism. Festivals attract tourists to local community events in order to promote enriching exchanges between tourists and residents.

This study will focus on the residents of the municipalities of Sombor and Apatin and measure their perception of festivals. The reason for studying perception of residents and not other stakeholders (such as, for example, businesses, politicians, pressure groups) in this study is rooted in the fact that residents are considered to play vital role in overall tourism development in the area and, in particular, in acceptance or rejection of an event based on their perceptions and attitudes towards it.

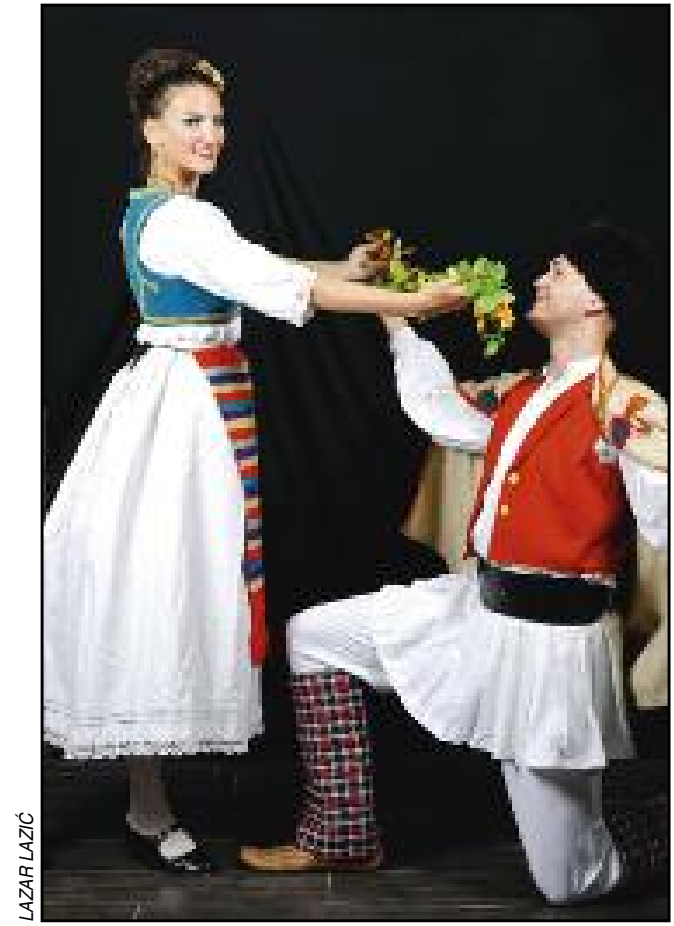

Figure 1: National costume of Bačka 


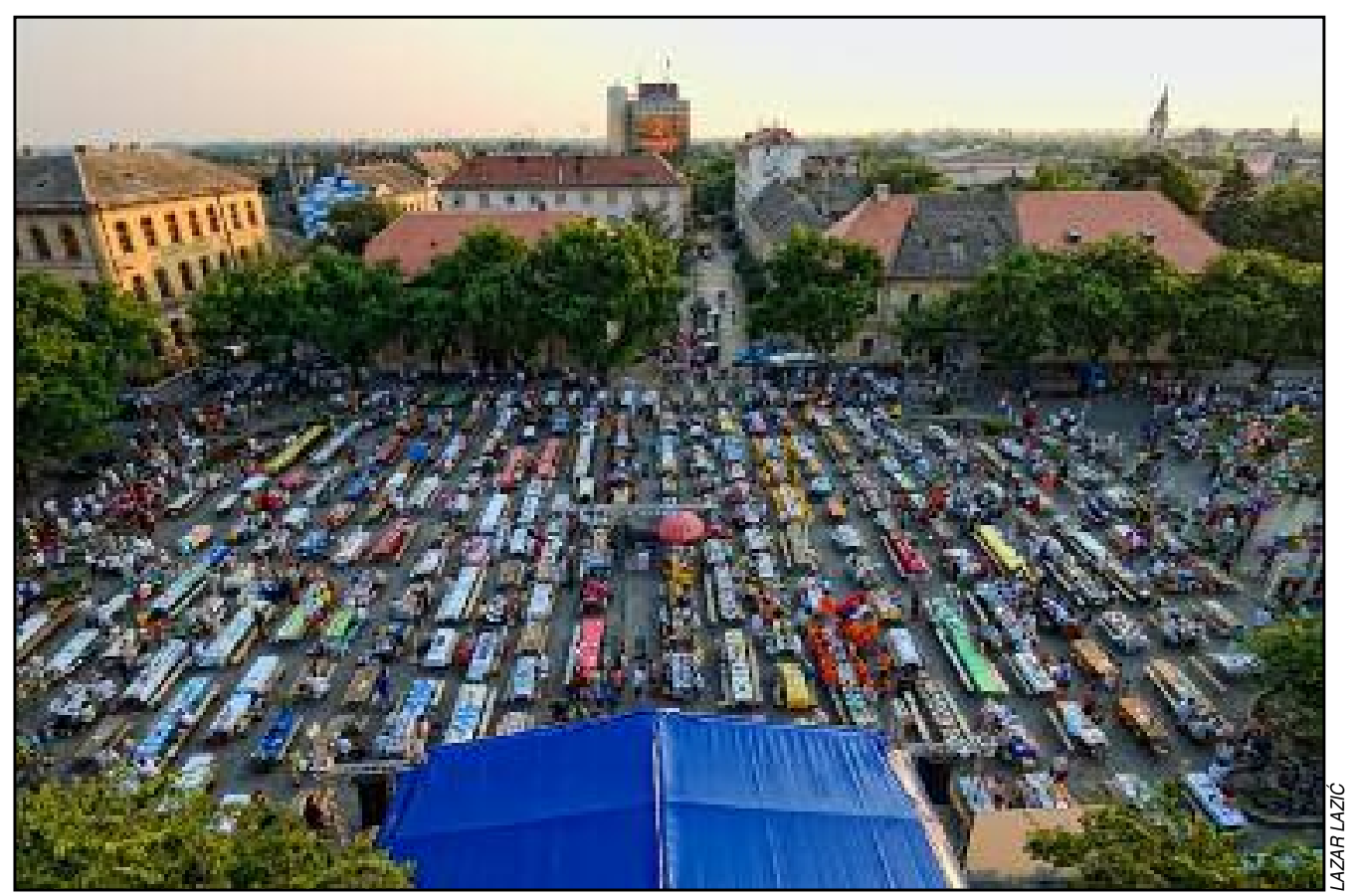

Figure 2: Sombor stew festival, Vojvodina Province, Serbia.

\section{Literature review}

The statement that tourism can lead to regional development has been well-documented by various researchers. Tourism has a multidimensional affection on the host destination. The direct and indirect benefits of tourism combine to create an extensive list of opportunities. In

both developed and developing countries, tourism is a mean of raising the economic activity of regions (Mangion and McNabb 2005; Skoultsous and Tsartas 2009; Pivac et al. 2011). Furthermore, it is widely perceived as a potential economic base, providing elements that may improve quality of life and has various social and environmental impacts (Andereck et al. 2005; Todorović and Bjeljac 2009). Tourism is an economic sector able to offer a significant contribution to the economic growth of a region and to the labour market and produces jobs directly and indirectly through the supply of goods and the necessary services for tourist activities. Moreover, tourism produces social benefits to the region (i.e. development of small and medium enterprises, creation of new job, improvement of infrastructure etc.). On cultural side, tourism is considered an element of community enrichment, thanks to the meeting of different cultures (Pivac etal. 2011; Blešić et al. 2013).

According to Lee et al. (2004) on a global scale festivals and events with a strong cultural component are substantially increasing in numbers. In addition to enhancing local pride in culture, these events also expose indigenous minorities and an increasing number of international visitors to new peoples and their customs as well as, other purposes including contributing to the local economy, and providing recreation opportunities (Long and Perdue 1990). Getz (1991) recognizes festivals and events as a new wave of alternative tourism which contributes to sustainable development and improves the relationship between host and guest.

Local festivals are increasingly being used as instruments for promoting tourism and boosting the regional economy (Felsenstein and Fleischer 2003). Getz (1993) and Formica and Uysal (1998) showed that the economic gains from festivals can be substantial because festivals provide interesting activities and spending venues for both local people and tourists. 


\section{Methodology}

Research of the local population attitudes was conducted on the territory of the municipalities of Sombor and Apatin that belong to the administrative district of the western Backa. The entire region covers the area of $2,420 \mathrm{~km}^{2}$, out of which $1,178 \mathrm{~km}^{2}$ belong to the municipality of Sombor and $333 \mathrm{~km}^{2}$ to the municipality of Apatin. The municipality of Sombor comprises of 16 settlements and the municipality of Apatin of 5 settlements (Internet 1; Internet 2). Although the area is characterized by depopulation and the aging of the population (Stojanović et al. 2014), this is a multiethnic area.

What makes this whole region a multiethnic one is the fact that there are 24 nationalities inhabiting it. The most numerous are: Serbs, Hungarians, Yugoslavs, Croats, Montenegrins, Ruthenians, Ukrainians, Poles, Germans, Albanians, Turkish, Czechs, and Slovaks. Melting point of different cultures, religions, nationalities and rural festivities are the base of anthropogenic rural tourism attractions in Vojvodina Province (Dragićević et al. 2013).

10 different events from the territories of the municipalities of Sombor and Apatin were included in the research: Sombor stew festival, Ravangrad wine fest, Street of old crafts, Horse carriage festival, Bodrog fest, Miholjdan meetings, Bunjevci festival of wheat harvesting (Sombor), Apatin fishermen's night, Gypsy night, and Grape harvesting festival in Sonta (Apatin). All these events represent the culture, tradition, folklore and gastronomy of the nations that inhabit this region.

The questionnaire used in this research was based on the Delamere scale (Delamere et al. 2001), which was modified and shortened for the purposes of a more efficient interviewing. The questionnaire used in this research consists of two parts (Internet 3). The first part of the questionnaire includes demographic questions while the second part of the questionnaire consists of 21 questions are aimed at measuring attitudes local population has toward events on the territory of the municipalities of Sombor and Apatin. Attributes were measured on a five-point Likert type scale ranging from 1 (strongly disagree) to 5 (strongly agree). The interviewing was conducted in the municipalities of Sombor and Apatin between April and June 2012. There were seven interviewers. In total, 300 questionnaires were distributed and 212 (71\%) usable questionnaires were obtained.

\section{Results}

\subsection{Characteristics of respondents}

The sample included 105 (49.5\%) males and 107 (50.5\%) females among the respondents. The main age group was under 21 years of age and represented $30.7 \%$ of the total group of respondents. The next biggest group was the group between 31 and 40 years of age, thus making $23.1 \%$ of the whole sample. Most of the respondents $(59 \%)$ had completed secondary education. Regarding their occupation, the majority of respondents are either employed (63.2\%) or students (33.5\%). 54\% of respondents come from the municipality of Sombor, out of which $54 \%$ come from the city of Sombor and other $46 \%$ from villages that belong to the municipality of Sombor (Bezdan, Backi Monostor, Stapar, Telecka, Kljajicevo). The other $46 \%$ of the respondents come from the municipality of Apatin, out of which $60 \%$, come from the town of Apatin and other $40 \%$ from surrounding villages (Sonta, Prigrevica, Kupusina, Svilojevo). The majority of respondents are of Serbian nationality (67.9\%), followed by those of Croatian nationality (17.9\%). Respondents of other nationalities make $14.2 \%$ of the sample.

\subsection{Factor analysis}

The attribute importance data were factor analyzed using the principal component method and varimax rotation procedure in order to extract the sub-dimensions of those attributes. In this study, all factors with eigenvalue greater than 1 and with factor loadings more than 0.5 were retained.

The results of the factor analysis, which suggested a five-factor solution, included 21 attributes and explained $65.43 \%$ of the variance. The Kaiser - Meyer - Olkin (KMO) overall measure of sampling adequacy was 0.74 which was middling (Kaiser 1974) and Bartlett's test of sphericity was significant $(p=0.000)$. Values of Cronbach alpha coefficient for the first four factors are in the domain of high reliability while 
Table 1: Respondents' demographic data $(\mathrm{n}=212)$.

\begin{tabular}{lrrlrr}
\hline Variables & Sample size & Percentage & Variables & Sample size & Percentage \\
\hline Age & & & Place of residence & & \\
$\leq 20$ & 65 & 30.7 & Apatin & 58 & 27.4 \\
$21-30$ & 16 & 7.5 & Sonta & 13 & 6.1 \\
$31-40$ & 49 & 23.1 & Prigrevica & 11 & 5.2 \\
$41-50$ & 43 & 20.3 & Kupusina & 4 & 1.9 \\
$51-60$ & 33 & 15.6 & Svilojevo & 11 & 5.2 \\
$61 \geq$ & 6 & 2.8 & Sombor & 62 & 29.2 \\
Gender & & & Bezdan & 14 & 6.6 \\
Male & 105 & 49.5 & Backi Monostor & 19 & 9.0 \\
Female & 107 & 50.5 & Stapar & 6 & 2.8 \\
Education & & & Telecka & 13 & 6.1 \\
primary education & 5 & 2.4 & Kljajicevo & 1 & 0.5 \\
secondary education & 125 & 59.0 & Nationality & & \\
higher education & 6 & 2.8 & Serbian & 144 & 67.9 \\
Master's degree & 74 & 34.9 & Croatian & 38 & 17.9 \\
Doctor's degree & 2 & 0.9 & Hungarian & 7 & 3.3 \\
Occupation & & & Romanian & 6 & 2.8 \\
student & 71 & 33.5 & Roma & 11 & 5.2 \\
employed & 134 & 63.2 & Montenegrin & 1 & 0.5 \\
retired & 1 & 0.5 & Slovak & 1 & 0.5 \\
unemployed & 6 & 2.8 & Gorani people & 4 & 1.9 \\
\hline
\end{tabular}

Table 2: Results of factor analysis.

\begin{tabular}{|c|c|c|c|c|c|}
\hline $\begin{array}{l}\text { Extracted } \\
\text { factors }\end{array}$ & Items & $\begin{array}{l}\text { Factor } \\
\text { loading }\end{array}$ & Eigenvalue & $\begin{array}{l}\text { Variance } \\
\text { explained }\end{array}$ & Cronbach's a \\
\hline F1 & $\begin{array}{l}\text { Event should be held on a suitable location with secured } \\
\text { parking space. } \\
\text { Event should be held without negative ecological influence. } \\
\text { Safety of visitors during the event is on high level. } \\
\text { Prices of product and services are affordable } \\
\text { (food, beverages, souvenirs). } \\
\text { Quality of products and services is exceptional } \\
\text { (food, beverages, souvenirs). }\end{array}$ & $\begin{array}{l}0.763 \\
0.805 \\
0.872 \\
0.845 \\
0.823\end{array}$ & 5.644 & 17.003 & 0.892 \\
\hline$\overline{F 2}$ & $\begin{array}{l}\text { Events make the number of tourists grow. } \\
\text { Events enable local community to make extra incomes. } \\
\text { Events have a positive economic influence. } \\
\text { Events help improve the quality of life in the area. }\end{array}$ & $\begin{array}{l}0.711 \\
0.850 \\
0.830 \\
0.611 \\
\end{array}$ & 3.205 & 13.657 & 0.808 \\
\hline F3 & $\begin{array}{l}\text { Event should be organized by local authority } \\
\text { (place of the organization of an event). } \\
\text { Event should be organized by professional societies. } \\
\text { Event enables exchange of ides among ethnic groups } \\
\text { in the community. } \\
\text { Events contribute to the feeling of belonging. } \\
\text { Events have a great influence on the improvement of human } \\
\text { relationships in local community. } \\
\text { Events positively influence cooperation between people. }\end{array}$ & $\begin{array}{l}0.583 \\
0.659 \\
0.711 \\
0.726 \\
0.630 \\
0.537\end{array}$ & 1.896 & 13.189 & 0.773 \\
\hline F4 & $\begin{array}{l}\text { Events should be entertaining. } \\
\text { Performance of famous musicians/singers is necessary. } \\
\text { Event should also have accompanying programs } \\
\text { (education, competitions, and workshops). }\end{array}$ & $\begin{array}{c}0.9 \\
0.822 \\
0.797\end{array}$ & 1.675 & 12.430 & 0.885 \\
\hline$\overline{F 5}$ & $\begin{array}{l}\text { Event should be promoted among different structures } \\
\text { of potential visitors. } \\
\text { Event should be promoted in neighboring countries. } \\
\text { Brochures promoting the exhibitors should be handed at the event. }\end{array}$ & $\begin{array}{l}0.693 \\
0.789 \\
0.728\end{array}$ & 1.342 & 9.151 & 0.682 \\
\hline
\end{tabular}


the fifth factor of Cronbach alpha coefficient is in the domain of acceptable reliability (Lehman et al 2005). This demonstrates that the scales of the formal questionnaire have considerable reliability (Nunnally 1978). Table 2 shows the results of the factor analysis.

The first factor was labeled »Services «. This factor explained $17.003 \%$ of the total variance with a reliability coefficient of 0.892 . The second factor was »Economic importance « explaining $13.657 \%$ of the total variance with a reliability coefficient of 0.808 . The third factor was labeled »Socialization « and explained $13.189 \%$ of the variance with a reliability coefficient of 0.773 . The fourth factor, labeled »Entertainment " accounted for $12.430 \%$ of the variance with a reliability coefficient of 0.885 . The fifth, »Promotion « explained $9.151 \%$ of the total variance, indicating a reliability coefficient of 0.682 .

Table 3: Mean ratings of factors and items.

\begin{tabular}{|c|c|c|}
\hline Selected factors and items & Mean & Std. Dev. \\
\hline F1 - Services & 4.0170 & 0.87584 \\
\hline Event should be held on a suitable location with secured parking space. & 4.1038 & 0.98259 \\
\hline Event should be held without negative ecological influence. & 4.2264 & 0.97147 \\
\hline Safety of visitors during the event is on a high level. & 4.0000 & 1.08850 \\
\hline Prices of product and services are affordable (food, beverages, souvenirs). & 3.7877 & 1.15494 \\
\hline Quality of products and services is exceptional (food, beverages, souvenirs). & 3.9670 & 1.03211 \\
\hline F2 - Economic importance & 4.5483 & 0.55049 \\
\hline Events make the number of tourists grow. & 4.5943 & 0.67842 \\
\hline Events enable local community to make extra incomes. & 4.5330 & 0.68418 \\
\hline Events have a positive economic influence. & 4.6745 & 0.62546 \\
\hline Events help improve the quality of life in the area. & 4.3915 & 0.76816 \\
\hline F3 - Socialization & 4.3546 & 0.55947 \\
\hline Events enable making business connections. & 4.3066 & 0.89514 \\
\hline Events are places where people relax and reveal everyday stress. & 4.0236 & 0.90518 \\
\hline Events enable exchange of ides among ethnic groups in the community. & 4.3302 & 0.94615 \\
\hline Events contribute to the feeling of belonging. & 4.3302 & 0.77547 \\
\hline Events have a great influence on the improvement of human relationships in local community. & 4.6462 & 0.63271 \\
\hline Events positively influence cooperation between people. & 4.4906 & 0.69861 \\
\hline F4 - Entertainment & 4.1824 & 0.85201 \\
\hline Events should be entertaining. & 4.3396 & 0.98218 \\
\hline Performance of famous musicians/singers is necessary. & 3.9245 & 0.95091 \\
\hline Event should also have accompanying programs (education, competitions, and workshops). & 4.2830 & 0.90029 \\
\hline F5 - Promotion & 4.2028 & 0.65250 \\
\hline Event should be promoted among different structures of potential visitors. & 4.0755 & 0.86203 \\
\hline Event should be promoted in neighboring countries. & 4.3019 & 0.83943 \\
\hline Brochures promoting the exhibitors should be handed at the event. & 4.2311 & 0.80188 \\
\hline
\end{tabular}

From the results shown in Table 3 we can conclude that the respondents consider the economic factor as the most important one, i.e. possibility to make extra incomes and increase the living standard in the community. It is followed by the third factor »Socialization « which reflects the importance of events for the improvement of human relationships and connections between people. The least important to the respondents are those questions connected to the factor »Services«, followed by questions referring to the factors of »Entertainment « and »Promotion «. Less favoured rural areas in Serbia rely on traditional economic activities as the main source of income and jobs. At the same time they possess unique cultural values which are not recognised as a development factor and consequently not properly managed. The main objective therefore should be to improve the management of cultural values in rural areas in order to contribute to economic and social development of less favoured rural areas.

\section{Discussion}

The rural areas in the municipalities of Sombor and Apatin (19 villages) have been neglected over the decades, especially in the context of sustainable tourism development (refers to any form of tourism). Moreover, development of rural tourism in multiethnic regions of Sombor and Apatin has been so far carried out 
by individuals (local enthusiasts) who lack adequate training. Being aware of severe negative impacts of living in the past twenty years, respondents consider economic factors as very important. They believe that good organization of one event makes number of tourists grow, enables extra incomes for local community, has a positive economic influence in general and improves the quality of life in the micro area. This consequently shall cause an increase in multiplier effects, such are: higher average wages per person, greater employment opportunities, better purchasing power, greater revenues etc.

The second most important factor for them is socialization. Inhabitants of this region are people who like to socialize, cooperate and collaborate among themselves and with others outside their municipalities. They easily express empathy towards other people and they are highly aware of the importance of environmental protection. Their opinion is that events enable making business connections and are places where people can relax and reveal everyday stress. Moreover, events enable exchange of ideas among ethnic groups in the community and contribute to the feeling of belonging. Also, events have a great influence on the improvement of human relationships in local communities and positively influence cooperation between people.

The least important factors for them are entertainment and promotion. According to the terms of reference of the international project SY_CULTour: Synergy of culture and tourism: utilisation of cultural potentials in less favoured rural regions, some of the goals that should be met by the end of the project are (Project documentation SY_CULTour, 2011-2014):

- better promotion of cultural heritage / tourist cultural route

- better employment opportunities for local people in the sector of tourism and on local farms

- preservation of tradition, traditional crafts and handicrafts

- preservation and presentation of un(der)used cultural value

\section{Conclusion}

The measurement of resident attitudes toward the social impacts of community festivals is of critical importance for both communities and for festival organizers. As community leaders and festival organizers become more conscious of the needs and priorities of the community, they can better respond to community con-

Figure 3: Bodrog fest - doll in Šokci national costume.

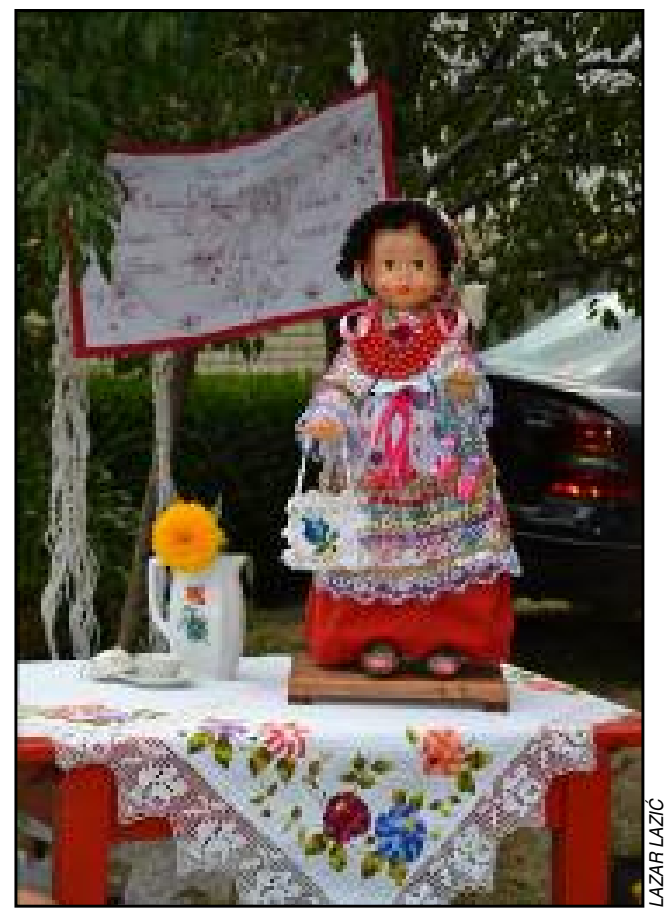


cerns and work together to maintain an appropriate balance between the social benefits and social costs that resulting from community festivals (Delamere et al. 2001). The findings of the study contribute to deeper understanding of resident attitudes toward the social impacts of community festivals and can be utilized by the organizers to increase the social benefits generated by the festival and reduce its negative social impacts. This study makes a significant contribution in the generation of items, testing of items, and the understanding of residents' attitudes toward social and economic impacts of community festivals. Residents and organizers both have a stake in maximizing social benefits and minimizing social costs that accrue from the festival. Economic impacts need to be taken into more serious consideration by the community and by festival organizers if the legacies of hosting the festival are to be viewed more positively by a greater portion of the residents of the community (Hall and Hodges 1996). This, in turn, will help permit festivals to be considered as based on their total contribution to the quality of life in Sombor and Apatin municipalities.

\section{Acknowledgment}

This study resulted as a part of National project of Ministry of Science and Technological Development: "Social relationship between Serbs and Croats, national identity and minority rights with regard to European integration«, No. 47024.

\section{References}

Andereck, K., Valentine, K., Knopf, R.Vogt, C. 2005: Residents' Perceptions of Community Tourism Impacts. Annals of Tourism Research 32-4. DOI: http://dx.doi.org/10.1016/j.annals.2005.03.001

Blešić, I., Pivac, T., Stamenković, I. Besermenji S. 2013: Motives of visit ethno music festivals with regard to gender and age structure of visitors. Event management 17.

Delamere, T., Wankel, L. Hinch, T. 2001: Development of a scale to measure resident attitudes toward the social impacts of community festivals, part I: Item generation and purification of the measure. Event Management 7-1.

Dragićević, V., Besermenji, S., Pivac, T., Ivkov - Džigurski A., Košić, K. 2013: Evaluation of tourist attractiveness and museum management in Sombor and Apatin (Serbia). Acta geographica Slovenica 53-2. DOI: http://dx.doi.org/10.3986/AGS53405

Felsenstein, D., Fleischer, A. 2003: Local Festivals and Tourism Promotion: The Role of Public Assistance and Visitor Expenditure. Journal of Travel Research 41. DOI: http://dx.doi.org/10.1177/0047287503251548

Formica S, Uysal M. 1998: Market segmentation of an international cultural-historical event in Italy. Journal of travel research 36-4. DOI: http://dx.doi.org/10.1177/004728759803600402

Getz, D. 1991: Festivals, Special Events and Tourism. Van Nostrand. New York.

Getz, D. 1993: Corporate culture in not-for-profit festival organizations. Festival Management and Event Tourism 1-1.

Getz, D. 1997: Events management and Event Tourism. New York.

Hall, C. M., Hodges, J. 1996: The party's great, but what about the hangover? The housing and social impacts of megaevents with special reference to the 2000 Sydney Olympics. festival management \& event tourism 4 .

Internet 1: http://www.sombor.rs/licna-karta-sombora-sombor-u-brojkama (10.11.2012).

Internet 2: http://www.soapatin.org/priroda.aspx (10.11.2012).

Internet 3: http://www.dgt.uns.ac.rs/survey.doc (1.3.2013)

Kaiser, H. F. 1974: An Index of Factorial Simplicity. Psychometrika 39.DOI: http://dx.doi.org/10.1007/bf02291575

Lee, C., Lee, Y., Wicks, B. 2004: Segmentation of festival motivation by nationality and satisfaction. Tourism Management 25-1. DOI: http://dx.doi.org/10.1016/s0261-5177(03)00060-8

Lehman, A., O'Rourke, N., Hatcker, L. Stepanski, E. J. 2005: JMP for Basic Univariate and Multivariate Statistics - A Step by Step Guide. SAS Institute Inc., Cary, North Carolina.

Long, P. T., Perdue, R. R. 1990: The economic impact of rural festivals and special events: Assessing the special distribution of expenditures. Journal of travel research 28-4. DOI:1 http://dx.doi.org/0.1177/ 004728759002800403 
Mangion, D., McNabb, Y. 2005: Perceived Impacts Of A Rural Tourism Event. Paper presented at 19th Conference of Australia and New Zealand Academy of Management. Canberra, Australia, 7-10 December, 2005.

Nunnally, J. C. 1978: Psychometric theory. New York.

Pivac, T., Blešić, I., Stamenković, I., Besermenji, S. 2011: Event management and consumer satisfaction in tourism industry. African journal of business management 5-34. DOI: http://dx.doi.org/10.5897/ AJBM11.1641

Project documentation of South East Europe - Transnational Cooperation Programme project, named: SYZ_CULTour - Synergy of culture and tourism: utilisation of cultural potentials in less favoured rural regions (2011-2014), Document reg. no.: INTRA-5018416, EoI and ID:SEE/B/0017/4.3/X.

Raj, R., Vignali, C. 2010: Creating Local Experiences of Cultural Tourism through Sustainable Festivals. European Journal of Tourism, Hospitality and Recreation 1-1.

Skoultsos, S., Tsartas, P. 2009: Event tourism: statements and questions about its impacts on rural areas. Tourismos: an international multidisciplinary journal of tourism 4-4.

Stojanović, V., Đorđević, J., Lazić, L., Stamenković, I., Dragićević, V. 2014: The principles of sustainable development of tourism in the Special Nature Reserve Gornje Podunavlje and their impact on the local communities. Acta geographica Slovenica 54-2. DOI: http://dx.doi.org/10.3986/AGS54407

Todorović, M., Bjeljac, Z. 2009: Rural tourism in Serbia as a way of development in undeveloped regions. Acta geographica Slovenica 49-2. DOI: http://dx.doi.org/10.3986/AGS49208 